Matthews, C. M. E. (1957). Physiol. med. Biol. 2, 36.

Matthews, C. M. E. (1958). Radioaktive Isotope in Klinik und Forschung, p. 310. München and Berlin: Urban und Schwartzenberg.

Müller-Eberhard, H. J., Kunkel, H. G. \& Franklin, E. C. (1956). Proc. Soc. exp. Biol., N.Y., 98, 146.

Myant, N. B. (1952). Clin. Sci. 11, 191.

Palade, G. E. (1956). J. biophys. biochem. Cytol. 2, Suppl. 85.

Pappenheimer, J. R. (1953). Physiol. Rev. 33, 387.

Perkins, W. J. \& Piper, E. A. (1959). Proc. int. Conf. Med. Electronics, Paris (in the Press).
Peterson, E. A. \& Sober, H. A. (1956). J. Amer. chem. Soc. 78, 751.

Porath, J. (1956). Biochim. biophys. Acta, 22, 151.

Rondle, J. M. \& Morgan, W. T. J. (1955). Biochem. J. 61, 586.

Sober, H. A. \& Peterson, E. A. (1958). Fed. Proc. 17, 1116.

Sterling, K. (1950). J. clin. Invest. 30, 1228.

Taliaferro, W. H. \& Talmage, D. W. (1956). J. infect. Dis. 99, 21.

Volwiler, W., Goldsworthy, P. D., MacMartin, M. D., Wood, P. A., MacKay, I. R. \& Fremont-Smith, K. (1955). J. clin. Invest. 34, 1126.

Biochem. J. (1960) 76, 487

\title{
The Lamellibranch Crystalline Style
}

\author{
BY K. BAILEY AND BETTY D. WORBOYS \\ Department of Biochemistry, University of Cambridge and Stazione Zoologica, Naples
}

(Received 16 February 1960)

The crystalline style in many lamellibranchs exists as an elongated rod in a diverticulum of the stomach, the anterior end jutting into the stomach. It is rotated by cilia of the style sac, so that at the higher $\mathrm{pH}$ of the stomach, and by friction against the gastric shield, the one end frays and disperses, entangling food particles. The structure is constantly renewed by the epithelial cells lining the sac (see Nelson, 1918), and in anaerobiosis may disappear and then reappear under favourable circumstances. The style occurs in a few, but not many, gastropods, e.g. in the slipper limpet, Crepidula fornicata, L., Patella (Mackintosh, 1925), Melanoides tuberculata Müller (Fish, 1955).

The function of the style has been considered by many workers, and it is now generally agreed that its purpose is digestive. Coupin (1900) found in the style of Cardium amylase activity, as did Mitra (1901) in Anodonta. The properties of this enzyme in the oyster were studied by Yonge (1926), who also reported the absence of catalase, protease and lipase from the style. Though it is quite certain that proteolytic activity is absent, a lipolytic enzyme was found by George (1952) in the style of Crassostrea virginica Gmelin, the ribbed mussel Modiolus demissus Dillwyn and of other species; also by Hozumi (1959) in that of the clam Venerupis philippinarum Adams and Reeve.

Lavine (1946), noticing that Visking casing became weakened by style extracts from certain clams including Mya arenaria L., suggested the presence of a cellulase, though pure cellulose fibre was not digested. Since then, cellulase has been reported in the styles of Ostrea edulis L. and
Mytilus (Newell, 1953); in the lamellibranch Caelatura, the gastropod Melanoides (Fish, 1955) and in the wood-boring lamellibranch Bankia indica nair (Nair, 1955). In Crassostrea virginica, Dean (1958) noted that various coloured algae suspended in a drop of sea water containing solid crystalline style became non-motile and the limiting membrane was indistinguishable after 10 15 min. This effect, which he calls 'a new property,' might appear too rapid to signify a cellulase, and it may well be due to an action on cell-wall lipid. It is not certain that the cellulase is derived from the secretory apparatus of the style sac, for it could be a component of the symbiotic spirochaetes usually found in the style. Walker \& Warren (1938) studied a rather similar spirochaete (Cytophaga) isolated from soil, which decomposed cellulose partly to carbon dioxide and partly to a nonreducing mucilage.

A reinvestigation of phenol-oxidase activity in the style, first demonstrated by Berkeley (1923), has shown that for Mytilus and Modiolus at least, the enzyme has the character of an ortho-phenolase (Johansson, 1945). Its role is obscure.

Coupin believed that the style consisted mainly of a mucous substance 'saturated' with digestive fluid, and Barrois (1889) considered the style matrix to consist of globulin with a trace of 'mucin' or 'chondrin'. Mackintosh (1925) came to a similar conclusion, but in reality the tests employed were not strictly specific for true globulin. There seems no doubt, however, that a mucoprotein is present. During an investigation of the tropomyosin A (paramyosin) component of the 
adductor of the large lamellibranch Pinna nobilis L. it was thought worthwhile to isolate the style and reinvestigate its nature in the light of newer methods developed for the study of mucoproteins. A preliminary account has already been published (Bailey, 1958).

\section{MATERIALS AND METHODS}

Treatment of styles. After storage at $-20^{\circ}$ the styles were dispersed in a homogenizer by addition of water and solid sodium bicarbonate to bring the $\mathrm{pH}$ to 8 . A small amount of insoluble material (fraction 1) was spun down, and to the supernatant liquid dilute acetic acid was added to maximum precipitation at $\mathrm{pH} 5$. Material remaining in the supernatant was precipitated with 2 vol. of acetone, and both precipitates were combined and redispersed at pH 8. The precipitation procedure was once more repeated, but this time the pH 5 and acetone precipitates were kept separate and freeze-dried (fractions 2 and 3 respectively). It seems unlikely that these fractions were actually different, since a 'pH 5 precipitate' after redispersing could again be divided into soluble and insoluble fractions.

An extract of the whole style was also investigated by dispersing as described above, dialysing against water and, after removal of a small sediment, it was precipitated with acetone after bringing to $\mathrm{pH} 5$ with acetic acid ("wholestyle fraction'). If to such an extract trichloroacetic acid is added (final concentration $2 \%$ ), very little precipitation occurs unless the mixture be heated. This slight precipitate was thought to represent the various enzymes discussed above, and was dried in acetone and ether for further investigation ('enzyme fraction'). The supernatant, expected to contain the mucoproteins of the style, was neutralized to $\mathrm{pH} 5$, and precipitated and dried in acetone ('mucoprotein fraction').

Methods of analysis. The methods used for the estimation of hexosamine, hexose and methylpentose have followed the general recommendations of Winzler (1955) and are derived from the following authors: hexosamine, the Elson-Morgan method as modified by Rimington (1940); protein-bound hexose, the method of Lustig \& Langer (1931) as used by Weimer \& Moshin (1952); methylpentose, the method of Dische \& Shettles (1948); hexuronic acid, the carbazole method of Dische (1947); sialic acid, the 'direct' Ehrlich reaction as employed by Gottschalk (1955). The chromatographic separation of carbohydrates on paper was carried out in the ethyl acetate-pyridine-water mixtures of Jermyn \& Isherwood (1949), and the spots were developed with aniline phthalate or with hexosamine reagents (Partridge, 1948).

Acetyl groups were estimated by the method recommended by Gibbons (1959), except that mixing of sample and conc. sulphuric acid was carried out in a freezing mixture before insertion in the Markham still.

Amino acid analysis was performed according to the improved column procedure of Moore, Spackman \& Stein (1958) and amide nitrogen by direct estimation (see Bailey \& Rüegg, 1960). Tryptophan was determined by the micromethod of Spies \& Chambers (1949), edestin being used as standard. Hexosamines were also investigated by the method of Gardell (1953), and we are grateful to Mr D. F. Elsden for this part of the analysis.

\section{RESULTS}

General properties of style material. The fresh weight of the style of a large Pinna is 0.2-0.3 g., of which $80 \%$ is water. As already mentioned, trichloroacetic acid produces only a small precipitate and heating at $\mathrm{pH} 7$ likewise produces only a slight haze. The atypical protein reaction of most of the material suggests that it consists of mucoprotein. Fraction 1 , the undispersed material, represented only $2.5 \%$ of the total nitrogen and was not investigated; fraction 2 (pH 5 precipitate) weighed $0.30 \mathrm{~g}$. and fraction 3 (acetone precipitate) $0.23 \mathrm{~g}$. The weight of material precipitating with trichloroacetic acid ('enzyme' precipitate) is about $7 \%$ of the non-dialysable substance of a whole-style extract.

Carbohydrate analyses. Tests for uronic acid and sialic acid were entirely negative. Paper chromatography of hydrolysates of fractions 2 and $3(4 \mathrm{hr}$. at $100^{\circ}$ in $3 \%$ nitric acid and $10 \mathrm{hr}$. at $100^{\circ}$ in $0.5 \mathrm{~N}$-sulphuric acid) showed the presence of hexosamine, galactose and fucose. Quantitative analysis with appropriate standards (galactose for hexose, rhamnose for methylpentose) gave the values reported in Table 1. There appear to be approximately equal amounts of hexosamine and hexose, and half as much methylpentose. In the wholestyle extract the carbohydrate moiety, converted into anhydro residues, amounts to $26.2 \%$ by weight of the style substance. By column chromatography the hexosamine in fraction 2 was found to consist of equal parts of glucosamine and galactosamine (49 and $51 \%$ respectively), existing originally in the $N$-acetylated form. The analyses do not indicate that the various fractions are fundamentally different in chemical composition.

Surprisingly, the trichloroacetic acid precipitate (enzyme fraction) still contains considerable hexosamine, which suggested that the true enzyme protein which may be expected to precipitate under these conditions is very small indeed (see also below).

The character and relative amounts of the carbohydrate components are so like those of the blood-group substances (especially A group, see Kabat, 1956) that Professor W. T. J. Morgan kindly consented to test fraction 2 for $\mathrm{A}, \mathrm{B}, \mathrm{H}$ and $\mathrm{Le}^{\mathrm{a}}$ activity. Moreover, Springer, Rose \& György (1954) have reported that whole extracts of oyster possess a fairly strong group A activity. The results of our tests, however, were entirely negative.

Amino acid analysis. The results in Table 2 are expressed in terms of protein proper and not of whole-style substance, i.e. the $\alpha$-amino nitrogen corresponding to a given amino acid is converted into the anhydrous weight of the amino acid, and all values are then summated. The total gives the amount of 'protein' derived from the column, and 
individual values can now be expressed as a percentage of the total. In turn, these values can also be expressed as residues $/ 10^{5} \mathrm{~g}$. of protein. Even if the recovery of individual amino acids is not absolutely quantitative, the losses are likely to be spread over the whole and will not cause serious error.

There is nothing very unusual in the amino acid pattern of whole-style protein, though it may be noted that, like the blood-group substances, the amounts of aliphatic hydroxy amino acids and proline are unusually high; but, unlike the bloodgroup substances, where aromatic residues are absent, there occurs a high proportion of these groups, especially of tyrosine. Cystine, methionine and tryptophan are also present. Although the amide nitrogen is corrected for ammonia arising by decomposition of hexosamine under the conditions of the distillation, it leads to the inference that the mucoproteins of the style possess an alkaline isoelectric point, i.e. base + amide groups exceed total dicarboxylic acids by 11 groups $/ 10^{5} \mathrm{~g}$. of protein. Judged by the $\mathrm{pH}$ of minimum solubility around $\mathrm{pH} \mathrm{5,} \mathrm{the} \mathrm{true} \mathrm{isoelectric} \mathrm{point} \mathrm{appears} \mathrm{to} \mathrm{be} \mathrm{on} \mathrm{the}$ acid side, and the amide value is probably still too high.

As noted above, the material precipitating in $2 \%$ trichloroacetic acid (enzyme fraction) still contains hexosamine, and the general pattern of amino acids present is not unlike the original material, except that the proline content is even higher, namely 124 groups $/ 10^{5} \mathrm{~g}$. of protein, as against a value of about 40 which might be expected for material representing a mixture of enzymes (Bailey, 1950). This fact suggests that the enzyme activities demonstrable in the style constitute a very small part of the whole-style substance. It seems likely that this 'enzyme fraction' precipitates with trichloroacetic acid because of its lower content of carbohydrate.

In a hydrolysis of whole-style substance, the amount of amino acid eluted from the columns,

Table 1. Carbohydrates of crystalline style

Results are expressed as g./100 g. of dry material. - Indicates that no measurements were made.

$\begin{array}{lcccc} & \mathrm{N} & \text { Hexosamine } & \text { Hexose } & \text { Fucose } \\ \text { Whole style } & 11 \cdot 2 & 11 \cdot 2 & 12 \cdot 2 & 5 \cdot 7 \\ \text { Fraction 2 } & 12 \cdot 0 & 12 \cdot 4 & 11 \cdot 5 & 6 \cdot 5 \\ \text { Fraction 3 } & 12 \cdot 4 & 10 \cdot 8 & 8 \cdot 3 & - \\ \text { Enzyme fraction } & - & 6 \cdot 2 & - & - \\ \text { Mucoprotein fraction } & - & 13 \cdot 5 & - & -\end{array}$

* Theoretical acetyl as percentage of free hexosamine: $24 \cdot 0$; found: $20 \cdot 7 \%$.

Table 2. Amino acid analysis of crystalline style

\begin{tabular}{|c|c|c|c|c|c|}
\hline & \multicolumn{2}{|c|}{$\begin{array}{l}\text { Wt. of anhydro amino } \\
\text { acid/100 g. of protein* }\end{array}$} & \multicolumn{3}{|c|}{ Residues $/ 10^{5} \mathrm{~g}$. of protein } \\
\hline & $\begin{array}{l}\text { Whole } \\
\text { style }\end{array}$ & $\begin{array}{l}\text { Enzyme } \\
\text { fraction }\end{array}$ & $\begin{array}{l}\text { Whole } \\
\text { style }\end{array}$ & $\begin{array}{l}\text { Enzyme } \\
\text { fraction }\end{array}$ & $\begin{array}{l}\text { Bovine oestrous } \\
\text { mucoid } \dagger\end{array}$ \\
\hline Aspartic acid & $10 \cdot 87$ & $14 \cdot 0$ & 95 & 122 & 59 \\
\hline Threonine & $8 \cdot 91$ & $8 \cdot 85$ & 81 & 88 & 224 \\
\hline Serine & $5 \cdot 29$ & $5 \cdot 1$ & 61 & 59 & 130 \\
\hline Glutamic acid & $10 \cdot 51$ & $11 \cdot 0$ & 82 & 86 & 76 \\
\hline Proline & $8 \cdot 47$ & $12 \cdot 0$ & 87 & 124 & 185 \\
\hline Glycine & $4 \cdot 38$ & $6 \cdot 35$ & 77 & 111 & 71 \\
\hline Alanine & $3 \cdot 20$ & $\mathbf{3} \cdot 5$ & 45 & 49 & 97 \\
\hline Cystine & $4 \cdot 28$ & 0.9 & 42 & 9 & Nil \\
\hline Valine & $5 \cdot 33$ & $5 \cdot 5$ & 54 & 56 & 58 \\
\hline Methionine & 1.90 & $1 \cdot 8$ & 14 & 14 & Nil \\
\hline Isoleucine & $4 \cdot 19$ & $3 \cdot 9$ & 37 & 35 & 15 \\
\hline Leucine & $5 \cdot 09$ & $4 \cdot 6$ & 45 & 41 & 39 \\
\hline Tyrosine & $10 \cdot 12$ & $6 \cdot 1$ & 62 & 37 & $?$ \\
\hline Phenylalanine & $4 \cdot 82$ & $4 \cdot 1$ & 33 & 28 & 29 \\
\hline Lysine & $5 \cdot 24$ & $6 \cdot 2$ & 41 & 49 & 23 \\
\hline Histidine & 1.84 & $1 \cdot 7$ & 13 & 12 & Nil \\
\hline $\mathrm{NH}_{3}$ & $(1 \cdot 51)$ & - & 108 & $-\neq$ & - \\
\hline Arginine & 4.07 & $4 \cdot 1$ & 26 & 26 & 34 \\
\hline \multirow[t]{2}{*}{ Tryptophan } & $2 \cdot 22$ & $-\ddagger$ & 12 & $-\ddagger$ & Nil \\
\hline & $100 \cdot 7$ & $99 \cdot 8$ & & & \\
\hline
\end{tabular}

* Excluding the carbohydrate portion: for method of calculation, see text.

$\dagger$ Calculated from Gibbons (1959).

\pm Not measured. 
assuming near-quantitative recovery, is also a measure of the protein moiety of the style. The analysis of Table 2 indicated a minimal protein content of $67 \%$. The carbohydrates of Table 1 , on the other hand, converted into anhydro residues and added to the acetyl content, amount to

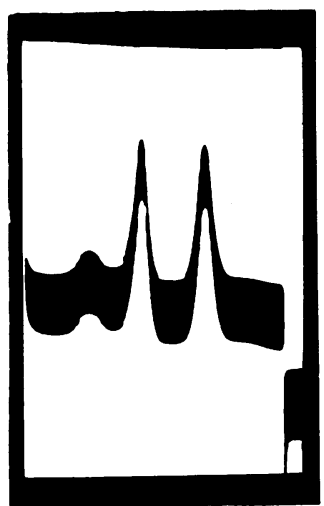

(a)

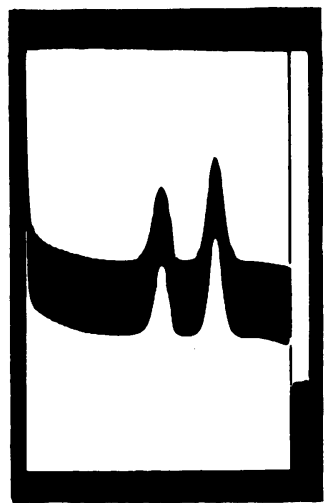

(b)
Fig. 1. Ultracentrifuge schlieren diagram for: $(a)$ wholestyle extract, concentration $1.5 \% ;(b)$ a fractionated product (fraction 2), concentration $0.9 \%$. KCl (I $0 \cdot 1)$ sodium phosphate $(I$ 0.028), $\mathrm{pH} \mathrm{7.5}$, was used. Exposure $64 \mathrm{~min}$. after reaching full speed $\left(269000 \mathrm{~g}\right.$ and $\left.20^{\circ}\right)$.

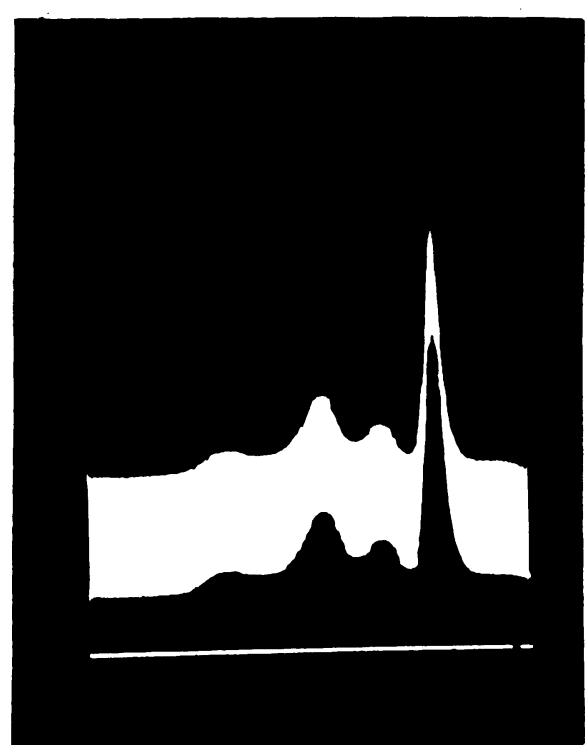

Fig. 2. Electrophoresis diagram of whole-style extract (ascending), concentration $1 \cdot 5 \%$. KCl-sodium phosphate was used as in Fig. 1; 100 v, $13 \mathrm{~mA}, 270 \mathrm{~min}$.
$28.6 \%$, indicating a protein content of $71.4 \%$. Considering the errors likely to exist in the carbohydrate determinations, these figures are very satisfactory.

Ultracentrifuge and electrophoretic data. In the ultracentrifuge the whole-style extract gives rise to three well-separated peaks (Fig. 1 $a$ ); at a total concentration of $1.5 \%(\mathrm{pH} \mathrm{7.5,I} 0 \cdot 128)$ there appear a small fast component $S_{20, w} 12.4$ and two major components $S_{20, w} 9 \cdot 3$ and 5.6. From the areas of the peaks the corresponding concentrations are 11,47 and $42 \%$ respectively. In fraction 2 (Fig. 1b), the heaviest component has disappeared, and the peaks corresponding to $S_{20,}, 9 \cdot 3$ and $5 \cdot 6$ are present in concentrations of 42 and $58 \%$ respectively. Although no serious attempts at fractionation have yet been made, these results indicate that separation by simple methods is feasible.

With electrophoresis (Perkin-Elmer apparatus, model 38) the system is more heterogeneous, four distinct peaks being visible, in which the slowest is the largest and sharpest (Fig. 2). Taken together, the results of ultracentrifuging and electrophoresis suggest that the style mucosubstance is not so very heterodisperse as to make fractionation difficult; but it is possible, of course, that the discrete peaks seen in the ultracentrifuge pattern represent not one but a collection of molecules of somewhat differing size.

\section{DISCUSSION}

Gibbons (1959), in his detailed study of purified undegraded cervical mucin, has emphasized that in reality there are few sources of epithelial mucins from which pure, unmodified material may be obtained. They occur in the presence of proteolytic enzymes, or exist as a mixture of secretions of various types, or are physically modified by incubation at body temperature. The crystalline style is a good example of a secretion which is rapidly produced, easy to isolate and belongs entirely to one class of mucoid, that of the hexosaminegalactose-fucose mucoproteins. Though active enzymically, the actual amount of enzyme protein (amylase, lipase, cellulase) appears to be negligible in terms of weight.

In the ultracentrifuge, the style substance appears as a paucidisperse system, though one must be cautious in supposing that the three peaks each represent single components. The nature of this heterogeneity is unknown. Part of the style substance which precipitates with trichloroacetic acid has a lower hexosamine content than the original, suggesting that components of differing protein content exist; also the amino acid composition of this protein differs in certain respects from whole-style protein. 
Little can be said about amino acid pattern other than that the proline-serine-threonine content is high, as in blood-group substances and cervical mucoids (see Table 2); but amino acids characteristically absent in these are present, with tyrosine in very large amounts.

\section{SUMMARY}

1. The nature of the mucoid comprising the substance of the lamellibranch crystalline style has been investigated in Pinna nobilis $\mathrm{L}$.

2. It consists of approximately $30 \%$ of carbohydrate combined with $70 \%$ of protein. The carbohydrate portion is composed of $\mathrm{N}$-acetylated glucosamine and galactosamine, galactose and fucose, which have been estimated. Although it resembles the blood-group substances in make-up, tests for $\mathrm{A}, \mathrm{B}, \mathrm{H}$ and $\mathrm{Le}^{\mathrm{a}}$ activity were negative.

3. All the usual amino acids are present, with threonine-serine, proline and tyrosine in relatively large amounts.

4. By weight, the amount of enzyme protein (amylase, lipase, cellulase) is negligible, but the style mucoid itself, both electrophoretically and in the ultracentrifuge, behaves as a paucidisperse system.

\section{REFERENCES}

Bailey, K. (1950). Chem. \& Ind. p. 243.

Bailey, K. (1958). Biochem. J. 69, 45 P.

Bailey, K. \& Rüegg, J. C. (1960). Biochim. biophys. Acta, 38, 239.
Barrois, T. (1889). Rev. Biol. Nord du France, 8-4, 124, 161,$163 ; 5,209,299,351$.

Berkeley, C. (1923). J. exp. Zool. 87, 477.

Coupin, H. (1900). C.R. Acad. Sci., Paris, 130, 1214.

Dean, P. (1958). Science, 128, 837.

Dische, Z. (1947). J. biol. Chem. 167, 189.

Dische, Z. \& Shettles, L. B. (1948). J. biol. Chem. 175, 595.

Fish, G. R. (1955). Nature, Lond., 175, 733.

Gardell, S. (1953). Acta chem. scand. 7, 207.

George, W. C. (1952). Biol. Bull., Woods Hole, 102, 118.

Gibbons, R. A. (1959). Biochem. J. 73, 209.

Gottschalk, A. (1955). Biochem. J. 61, 298.

Hozumi, M. (1959). Sci. Rep. Tokyo Bunrika Daig. 9, 37.

Jermyn, M. A. \& Isherwood, F. A. (1949). Biochem. J. 44, 402.

Johansson, J. (1945). Ark. Zool. 36, no. 13, 1.

Kabat, E. A. (1956). Blood Aroup Substances. New York: Academic Press Inc.

Lavine, T. F. (1946). J. cell. comp. Physiol. 28, 183.

Lustig, B. \& Langer, A. (1931). Biochem. Z. 242, 320.

Mackintosh, N. A. (1925). Quart. J. micr. Sci. 69, 317.

Mitra, S. B. (1901). Quart. J. micr. Sci. 44, 591.

Moore, S., Spackman, D. H. \& Stein, W. H. (1958). Analyt. Chem. 30, 1185.

Nair, N. B. (1955). Curr. Sci. 24, 126.

Nelson, T. C. (1918). J. Morph. 81, 53.

Newell, B. S. (1953). J. Mar. biol. Ass. U.K. 32, 491.

Partridge, S. M. (1948). Biochem. J. 42, 251.

Rimington, C. (1940). Biochem. J. 34, 931.

Spies, J. R. \& Chambers, D. C. (1949). Analyt. Chem. 21, 1249.

Springer, G. F., Rose, C. S. \& György, P. (1954). J. Lab. clin. Med. 43, 532.

Walker, E. \& Warren, F. L. (1938). Biochem. J. 32, 31.

Weimer, H. E. \& Moshin, J. R. (1952). Amer. Rev. Tuberc. 68, 594.

Winzler, R. J. (1955). Meth. biochem. Anal. 2, 279.

Yonge, C. M. (1926). J. Mar. biol. Ass. U.K. 14, 295.

Biochem. J. (1960) 76, 491

\title{
Carbohydrate Metabolism in Spirochaeta recurrentis
}

\section{THE METABOLISM OF SPIROCHAETES IN VIVO AND IN VITRO*}

\author{
By J. D. FULTON AND P. J. C. SMITH \\ National Institute for Medical Research, Mill Hill, London, N.W. 7
}

(Received 21 January 1960)

In contrast with the intensive studies on bacteria, very few investigations have been carried out on the biochemical activities of the order Spirochaetales, whose three main divisions comprise Spirochaeta (Borrelia), Leptospira and Treponema. The review

* Part of a Ph.D. thesis submitted to the University of London.

$\dagger$ Present address: Medical Research Council, Rheumatism Research Unit, Manor Hospital, Bath, Somerset. by Geiman (1952) on spirochaete metabolism emphasizes how little is known of this interesting group of micro-organisms. The intermediate taxonomic position of spirochaetes between bacteria and Protozoa, and the difficulty in cultivating pathogenic types in vitro, may account for this neglect.

Earlier workers (Fenyvessy \& Scheff, 1930; Scheff, 1935) reported that Spirochaeta recurrentis 